\title{
How Have FDI Flows Effected to Current Account Balance: In Turkey Case
}

\author{
Taner Akçaci \\ University of 7 Aralık Kilis, Kilis, Turkey \\ Onur Akkaya \\ University of Surrey, London, United Kingdom
}

\begin{abstract}
The purpose of this paper is to study the foreign direct investment flows of Turkey contributed to fragility to financial crisis by causing chronic current account deficits and was concerned with a slowdown in export growth prior to the financial crisis. This recommends that when analyzing a country's fragility to financial crisis, underscore should not only be placed on the reversibility of flows furthermore on the macroeconomic effect of these flows. The data set used for the empirical analysis in this paper consists of annual observations extending from 1982 to 2008 on Foreign Direct Investment (FDI) and Current Account (CA) in the Turkish economy. All variables are expressed in US Dollar (\$). Data were obtained from IMF Database (2010). The empirical evidence shows that foreign direct investment influent directly to current account balance. However, current account balance does not impressive to foreign direct investment. These reasons are merging with economics weakness and slowdown in export growth rate. Current account deficit is growth faster than past. Finally, the post-financial crisis impacts are deeply than the preliminary-financial crisis impacts for Turkey.
\end{abstract}

Keywords: Foreign Direct Investment (FDI), current account balance, variability, Turkey

\section{Introduction}

Nowadays, the main serious problem of emerging countries is current account deficit, especially for these countries lived in an economic crisis which based on a finances crisis. These countries' export is drop down suddenly. However, the import is staying the same level or increasing a bit more than past. As a result of these countries have a temporary current account deficit which causes a weakness economics situation, this event affected to emerge countries' growth rate. There is a strong positive association between the growth of manufacturing output and the rate of growth of GDP holds for the emerging countries.

In this context, Turkey is an emerging country and has the same reasons in this event. Then, Turkey's efficient growth rates prior to the crisis can be readily attributed to the rate of expansion of the manufactured sector and its export performance. We analyzed that foreign direct investment and current account balance effect on relationship each other in Turkey case. We discuss it in an empirical evidence chapter of the paper.

We investigated that foreign direct investment and current account balance's trends have been changing

Taner Akçaci, Assistant Professor, Dr., Department of Economics, University of 7 Aralık.

Onur Akkaya, Ph.D. Research Student, School of Economics, University of Surrey.

Correspondence concerning this article should be addressed to Onur Akkaya, School of Econimics, University of Surrey. E-mail: o.akkaya@surrey.ac.uk. 
during 1982 to 2008 in Turkey case. In this period, foreign direct investment had been a steady state situation during 1982 to 2004. Then, it was dramatically increased after three years. Finally, it has been decreasing slowly since 2007. On the other hand, current account balance has a fluctuate situation during 1982 to 2002. Especially, current account balance’s trend has decreased since 2002.

\section{Literature Review}

One of the most important indicators of crises are the current account deficit, external debt, paying current account deficit grows in a country where the crisis had gone which stated that the outcome devaluation. Before the Mexican crisis, the country's current account deficit and those high levels of financing the current account balance has been financed by portfolio investments stated that this situation may cause the crisis. In connection with such increase of capital movements in the 1990s, economists in the rising current account balance vulnerabilities have expressed concern of that. Matsubayashi (2005) examined whether the U.S. current account deficit was sustainable. According to the model used in this study the sustainability of current account deficit, private savings and private investment, budget balance, net of net foreign debt-government debt, and finally a stable co-integration relationship between variables depends on the availability of national savings. The study has estimated the co-integration equation using four different delay lengths and the U.S. current account deficit is likely to be sustainable concluded.

Stiglitz (2000) suggested that foreign direct investment was not as variability as destructive. It is compulsive as such an investment brings with it. Not only resources but also technology, entry to markets, an refinement in human capital are in favour of obtaining and sustaining foreign direct investment flows. Dooley and Gottschalk (1994) who detected that a high level of foreign direct investment was related to excessive but not lower variability. Singh (2002) demurred this opinion comes up with a number of discussions to assert that unfettered foreign direct investment is not in the best relevancies of emerging countries. Firstly, he discussed that like other reserve of finance, foreign direct investment can also come in surges. Secondly, it considering to the International Monetary Fund (IMF) balance of payments rules on the other side comprises of catcher profits and profits are affected by the business cycle, they display considerable variability.

Hausmann and Fernández-Arias (2000) have detected in the case of Latin America that the standard deviation of foreign direct investment is not very different from that of total net flows especially and that the variability of foreign direct investment itself has been on the increase. In addition to this, the total share of foreign direct investment in capital flows had been increasing in many emerging countries throughout the 1990s. In despite the fact that it has become the single largest piece of capital flows for emerging countries, this has not been compared by depletion variability in international capital markets or a decreased orbit of financial crisis.

Siddiqui and Ahmad (2007) have examined the question of whether foreign direct investment, Granger-cause current account deficits or vice versa. Theirs paper has examined the long run relationship between foreign direct investment and current account in Pakistan using quarterly data for the period 1976-2005. The empirical investigation consists of: (1) the application of co-integration analysis to ascertain the long run relationship between FDI and CA; and (2) the determination of the direction of causality among the variables in the context of vector error correction model. The results indicate that FDI and CA are co-integrated and thus exhibit a reliable long run relationship. The results indicate that the causality between 
FDI and CA is unidirectional: There is only one-way long run causality from FDI to CA, however, no long run causality, in the Granger sense, was found in opposite direction. Similarly, there is no short run causality from FDI to CA and vice versa. Therefore, as a policy implication, they should stress the fact that the significant effects that FDI inflows may cause to the deterioration of the balance of payments in the long run (due to profit remittance) and should be taken into account when policy makers decide to implement policies to attract foreign investors. In case of Pakistan, these investments could not contribute towards income generating activities, rather raising conspicuous import based on consumption, making high returns and repatriating the proceeds back home. Hence, the economic activities generated by these investments are not sustainable leading to low future growth and high present inflation through pressurizing the exchange rate and making current imports, which are largely inelastic, more expensive. Hence, foreign investment flows in tradable sectors, such as exports, should be encouraged where value addition and enhancing peoples' real incomes and savings should be preferred, and where the foreign capital flows would instead of causing pressure on current accounts, produce export proceeds through value addition. Here foreign investments could be beneficial since profit outflows would matched or even less than the export based inflows and hence, making positive impact on current account.

\section{Methodology}

The concept of Granger causality starts with the premise that the future cannot cause the past. If event A occurs after event B, then A cannot cause B. Granger (1969) applied this concept to economic time series to determine whether one time series "causes" in the sense of precedes another. However, merely because event A occurs before B does not mean that A causes B.

Consider the case of two variables $x_{t}$ and $y_{t}$.Then $x_{t}$ does not cause $y_{t}$ if, in a regression of $y_{t}$ on lagged $x_{t}$ and lagged $y_{t}$ then all the coefficients on the former are zero. Formally, in the regression:

$$
y_{t}=\sum_{i=1}^{p} \alpha_{i} y_{t-i} \sum_{i=1}^{p} \beta_{i} x_{t-i}+u_{t}
$$

Then $x_{i}$ does not cause $y_{t}$ if $\beta_{i}=0, i=1, \ldots, p$. A test of Granger non-causality can be based on a test of the hypothesis that this test is only valid asymptotically since the regression includes lagged dependent variables, but in practice, standard $F$-tests are often used.

The various definitions can be compared by considering the simple bivariate dynamic model:

$$
\begin{aligned}
& x_{1}=\alpha_{2} y_{t}+\beta_{21} y_{t-1}+\beta_{22} x_{t-1}+\varphi_{t} \\
& y_{1}=\alpha_{1} x_{t}+\beta_{11} y_{t-1}+\beta_{12} x_{t-1}+\gamma_{t}
\end{aligned}
$$

where the error terms $\varphi_{t}$ and $\gamma_{t}$ are assumed to be independent. If $\alpha_{2}=0$ then $x_{t}$ is predetermined for $y_{t}$ in the first equation. If $x_{2}=0$ and $\beta_{21}=0$ then $x_{t}$ is strictly exogenous for $y_{t}$ in the first equation. In this model, the condition $x_{2}=0$ is sufficient for $x_{t}$ to be weakly exogenous for estimation of the parameters $x_{1}$, $\beta_{11}$ and $\beta_{12}$ in the first equation. The condition $x_{2}=0$ is thus the condition under which the parameters $x_{1}$, $\beta_{11}$ and $\beta_{12}$ can be efficiently estimated by OLS on the first equation. In this model, weak exogeneity coincides with predeterminedness. However, in more general models, the two definitions will results in different conditions. If $\alpha_{2}=0$ and $\beta_{22}=0$ then $y_{t}$ does not Granger cause $x_{t}$. Thus, in this model Granger non-causality happens to coincide with strict exogeneity. In general however, Granger causality is neither necessary nor sufficient for (weak) exogeneity (Pierse \& Forchini, 2011). 


\section{Empirical Results}

\section{Data Base and Variable}

The data set used for the empirical analysis in this paper consists of annual observations extending from 1982 to 2008 on Foreign Direct Investment (FDI) and Current Account (CA) in the Turkish economy. All variables are expressed in US Dollar (\$). Data were obtained from IMF Database (2010).

\section{Result}

The first step of econometric analysis is to test for the unit roots of the series, for which different tests are described in the literature. We employed Augmented Dickey-Fuller (ADF) (1979) tests to check the non-stationary assumption. Appendix Table A1 reports of various unit root tests developed by ADF.

For both series the null hypothesis that a unit root exists was not rejected using the ADF test. A first difference filter was used, and subsequent Dickey-Fuller tests revealed that the data had been rendered stationary. Thus, the CA and FDI flows are both I (1), that is, integrated of order one (see Appendix Table A1).

As a second step a co-integration test was performed. The results of the co-integration test reported in Appendix Table A2 are based on a VAR selected by the SBC model selection criterion.

Starting with the null hypothesis of no co-integration $(r=0)$ among the variables, the maximal eigenvalue statistic is 32.3491 which is over the 95 percent critical value of 14.2646 . Hence, the null hypothesis of $r=0$ in favour of the general alternative $r=1$ cannot be rejected. Turning to the trace test, the null hypothesis of no co-integration ( $r=0)$ also can be rejected in favour of the alternative.

As there is evidence of co-integration, the standard Granger causality test was applied by estimating bivariate regressions of the form:

$$
\begin{aligned}
& x_{1}=\alpha_{2} y_{t}+\beta_{21} y_{t-1}+\beta_{22} x_{t-1}+\varphi_{t} \\
& y_{1}=\alpha_{1} x_{t}+\beta_{11} y_{t-1}+\beta_{12} x_{t-1}+\gamma_{t}
\end{aligned}
$$

For all possible pairs of $(x, y)$ series in the group, the reported F-statistics are the Wald statistics for the joint hypothesis:

$$
\beta_{1}=\beta_{2}=\beta_{3}=\cdots=\beta_{n}=0
$$

For each equation, the null hypothesis is that $y$ does not Granger-cause $x$ in the first regression and that $x$ does not Granger-cause $y$ in the second regression. The test result is from Appendix Table A3.

Empirical evidence of Granger causality test says that FDI causes CA. On the other hand, CA does not cause FDI. These evidences show that FDI has strongly influence to CA in the Turkey context.

\section{Conclusions}

Several researchers have examined that financial crisis has strongly relationship between short-term flows. But how have long-term flows such as FDI affected financial crisis. We analyzed this event in Turkey case. Turkey experience of financial crisis challenges the customary sagacity and has depth implications for other developing countries exploring to centre of attraction for FDI flows as a source of long-term steadfast financing.

The Turkey economy lived to an economic crisis which based on a finances crisis. This export is drop down suddenly. However, this import is staying the same level or increasing a bit more than past. As a result of these countries have a temporary current account deficit which causes a weakness economics situation. This event affected the economic growth rate. There is a strong positive association between the growth of 
manufacturing output and the rate of growth of GDP holds for Turkey.

We look into the relationship between foreign direct investment and current account. A lot of variables, such as foreign direct investment, influent into current account balance. The empirical evidence shows that foreign direct investment influent directly to current account balance. However, current account balance does not impressive to foreign direct investment. These reasons are merging with economics weakness and slowdown in export growth rate. Current account deficit is growth faster than past. Finally, the post-financial crisis impacts are deeply than the preliminary-financial crisis impacts for Turkey.

All in all, based on the assumption that the solution will be enabled from resources instead off results, some solutions will be suggested. The first one is that the perception which makes Turkey depends on foreign countries as regards input and production resources should be changed. Also the domestic production should be increased regarding the current competition conditions and it should reach the sustainable balance level of public sector. When domestic saving increased, also the domestic production will increase. In conclusion, this solution points out that, the importance of adverse result of both foreign trade liberalization and financial liberalization would disappear.

\section{References}

Adedeji, O. S., Handa, J., \& Darku, A. B. (2005). The balance of payments, analysis of developing economies: Evidence from Nigeria and Ghana. İngiltere: Ashgate Publishing Ltd..

Akçay, C., \& Şule, Ö. (1998). Current account position of the Turkish economy: Is there any cause for concern? Boğaziçi Journal Review of Social, Economic and Administrative Studies, 12(1), 35-39.

Calderon, C. A., Chong, A., \& Vloayza, N. (2002). Determinants of current account deficits in developing countries. Macroeconomics, II(1), 56-75.

Calvo, G. (1998). Capital flows and capital market crises: The simple economics of sudden stops. Journal of Applied Economics, 1(1), 35-54.

Dickey, D. A., \& Fuller, W. A. (1979). Distribution of the estimators of autoregressive time series with a unit root. Journal of the American Statistical Association, 74, 427-431.

Dooley, M. D., \& Gottschalk, P. (1984). Earnings inequality among males in the United States: Trends and the effect of labor force growth. Journal of Political Economy, 2(1), 59-89.

Doraisami, A. (2007). Financial crisis in Malaysia: Didi FDI flows contribute to vulnerability? Journal of International Development, 19, 949-962.

Edwards, S. (2001). Does the current account is matter. NBER Working Paper No. 8275.

Engle, R. F., \& Granger, C. W. J. (1987). Cointegration and error correction: Representation, estimation and testing. Econometrica, 55, 251-276.

Ersel, H. (1996). The timing of capital account liberalization: The Turkish experience. New Perspectives on Turkey, 15, 45-64.

Fry, M. J. (1993). Unstable current account behavior and capital flows in developing countries. In D. K. Das (Ed.), International finance: Contemporary issues. London: MacMillian Press.

Hausmann, R., \& Fernández-Arias, E. (2000). Getting it right: What to reform in international financial markets. Research Department Publications 4223, Inter-American Development Bank, Research Department.

Mackinnon, J. G. (1996). Numerical distribution functions for unit root and cointegration tests. Journal of Applied Econometrics, 11, 601-618.

Mann, C. L. (2002). Perspectives on the US: Current account deficit and sustainability. Journal of Economic Perspectives, 16(3), 131-152.

Matsubayashi, Y. (2005). Are US current account deficits unsustainable? Testing for the private and government intertemporal budget constraints. Japan and the World Economy, 17, 223-237.

McGettigan, D. (2000). Current account and external sustainability in the Baltics, Russia and other countries of the Former Soviet Union. IMF Occasional Paper, No. 189.

Milesi-Ferretti, G. M., \& Razin, A. (1996a). Current-account sustainability. Princeton Studies in International Finance No. 81, International Finance Section, Department of Economics, Princeton University. 
Milesi-Ferretti, G. M., \& Razin, A. (1996b). Current-account sustainability: Selected East Asian and Latin American experiences. NBER Working Paper, No. 5791.

Milesi-Ferretti, G. M., \& Razin A. (1996c). Sustainability of persistent current account deficits. National Bureau of Economic Research Working Paper, No. 5647.

Milesi-Ferretti, G. M., \& Razin, A. (1996d). Current-account sustainability: Selected Each Asian and Latin American experiences. NBER working Paper, No. 4893.

Ostry, J. D. (1997). Current account imbalances in ASEAN countries: Are they a problem? IMF Working Paper No.97/51.

Özmen, E. (1998). Current account deficits, macroeconomic policy stance and governance: An Reisen, Helmut. Sustainable and Excessive Current Account Deficits. OECD Development Centre, Technical Paper No. 132.

Pierse, R., \& Forchini, G. (2011). Econometrics lecturer notes. London: University of Surrey.

Rudiger, D., \& Alejandro, W. (1994). Growth, brookings, economic studies program. The Brookings Institution, 25(1), $253-316$.

Salop, J., \& Stipaller, E. (1980). Why does the current account matter? International Monetary Fund Staff Papers No. 27.

Siddiqui, D. A., \& Ahmad, M. H. (2007). The causal relationship between foreign direct investment and current account: An empirical investigation for Pakistan economy. MPRA Paper.

Singh A. (2002). Capital account liberalization, free long-term capital flows, financial crises and economic development. ESRC Centre for Business Research Working Paper No. 245, University of Cambridge.

Stern, R. M. (1997). The balance of payments. Chicago: Adline Publishing.

Stiglitz, J. (2000). Capital market liberalisation, economic growth and stability. World Development, 28(6), 1075-1086.

Togan, S., \& Ersel, H. (2005). Current account sustainability: The case of Turkey (pp. 6-7). Ankara: Congress of European Union.

Utkulu, U., \& Özdemir, D. (2003). Does trade liberalization cause a long-run economic growth in Turkey. İstanbul Bilgi Üniversitesi Working Papers, No. 03/19.

Ventura, J. (2002). Towards a theory of current accounts. NBER Working Papers No. 9163.

\section{Appendix A}

Table A1

ADF Unit Root Test Result

\begin{tabular}{llll}
\hline Valuables & \multicolumn{1}{c}{$\mathrm{I}(0)$} & $\mathrm{I}(1)$ & Co-Integration Level \\
\hline & Constant and Trend & Constant and Trend & \\
FID & $-3.2138(1)$ & $-4.5234^{*}$ & $\mathrm{I}(1)$ \\
CUR & $0.2608(1)$ & $-4.2321^{* *}$ & $\mathrm{I}(1)$ \\
\hline
\end{tabular}

Notes. $^{* *}$ denotes unit root at 5\% significance level, numbers in parenthesis are optimum number of lags determined according to AIC, critical values are based on MacKinnon (1996). For PP and KPSS tests, numbers in parenthesis are the truncation lag determined according to Bartlett Kernel (1992). ${ }^{* * *},{ }^{* * *}$ shows respectively 1\%, 5\%, $10 \%$ level Ho hypothesis.

Table A2

ADF Co-integration LR Test Based on Maximal Eigen Value of the Stochastic Matrix With Unrestricted Intercepts and Restricted Trends in The VAR

\begin{tabular}{lllll}
\hline Test & Null & Alternative & Statistic & 95\% critical value \\
\hline Max-eigenvalue & $r=0$ & $r=1$ & 32.3491 & 14.2646 \\
Trace & $r=0$ & $r=1$ & 36.4505 & 15.4947 \\
\hline
\end{tabular}

Note. Max-eigenvalue and Trace test indicates two co-integrating eqn(s) at the 0.05 level.

Table A3

Granger Causality Test Results

\begin{tabular}{lcl}
\hline Null Hypothesis: & F-statistic & Prob. \\
\hline FDI does not Granger cause CA & 3.4842 & 0.074 \\
CA does not Granger cause FDI & 11.5063 & 0.002 \\
\hline
\end{tabular}


Appendix B

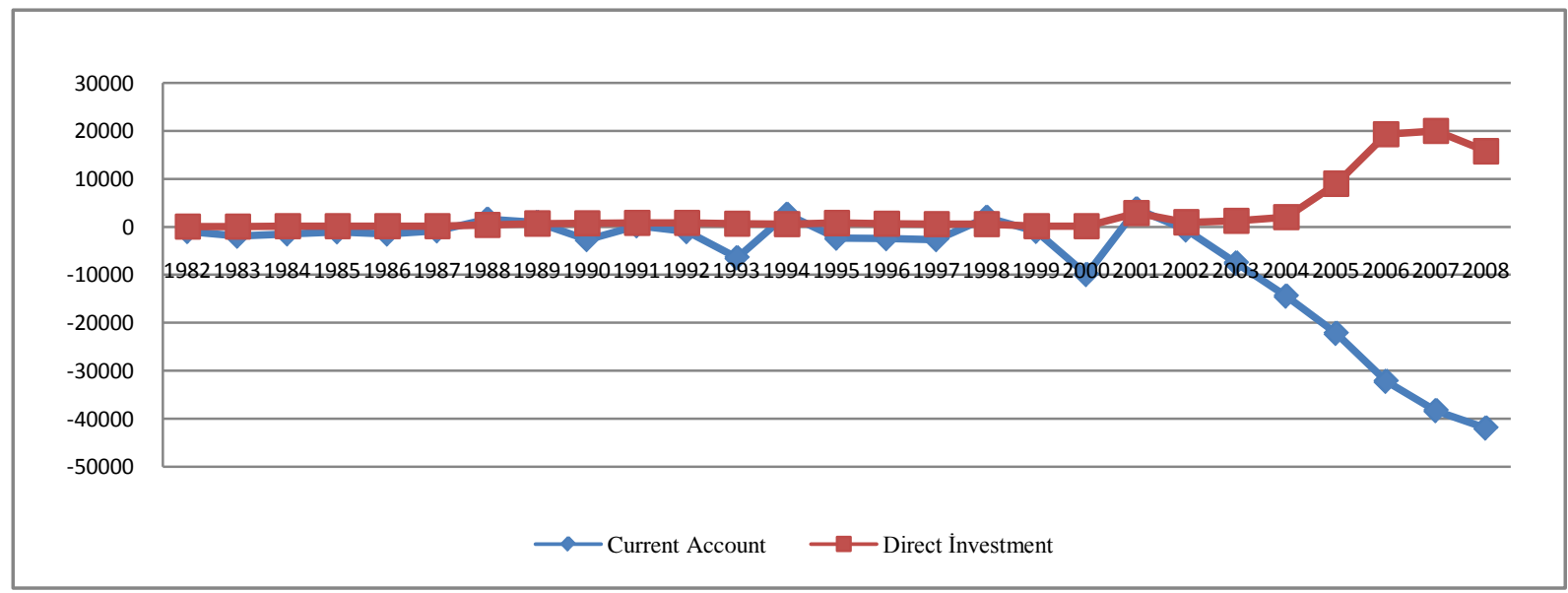

Figure B1. Current account and FDI change by year. 